\title{
Okuma Alışkanlığının Kazandırılmasına İlişkin Öğretmen Görüşlerinin Incelenmesi*
}

\section{The Investigation of Teachers' Opinions about Gaining Reading Habits}

\author{
Yaşar Çelik ${ }^{\mathrm{a}, * *}$ \\ ${ }^{a}$ Dr. Öğr. Üyesi, Ondokuz Mayıs Üniversitesi, Eğitim Fakültesi, Temel Eğitim Bölümü, 55139, Samsun/Türkiye. \\ ORCID: 0000-0001-8159-5189
}

\section{MAKALE BILLGISI}

\section{Makale Geçmişi:}

Başvuru tarihi: 05 Kasım 2019

Düzeltme tarihi: 07 Ocak 2020

Kabul tarihi: 29 Ocak 2020

\section{Anahtar Kelimeler:}

Okuma alışkanlı̆̆

Öğretmen

Görüş

\section{ART ICLE INFO}

\section{Article history:}

Received 05 November 2019

Received in revised form 07 January 2020

Accepted 29 January 2020

\section{Keywords:}

Reading habit,

Teacher

Opinion
ÖZ

İlkokul öğretmenlerinin öğrencilerine okuma alışkanlığı kazandırmada karşılaştıkları sorunları, kullandıkları stratejileri ve okuma alışkanlığı kazandırmaya yönelik görüş ve önerilerini tespit etmeyi amaçlayan bu araştırma durum çalışması deseninde nitel bir çalışmadır. Araştırmada amaçlı örnekleme yöntemlerinden kolay ulaşılabilir durum örneklemesi kullanılmıştır. Araştırmaya, 20182019 eğitim-öğretim y1lında, devlet ilkokullarında görev yapan 76 öğretmen katılmıştır. Araştırma verileri yarı yapılandırılmış görüşme formu ile elde edilmiştir. Verileri elde etmek amacıyla dört araştırma sorusu sorulmuştur. Veriler içerik analizi ile analiz edilmiştir. Araştırma sonucunda, öğretmenlerin okuma alışkanlığı kazandırırken meslektaşlarına örnek olabilecek birçok strateji kullandıkları; aileden, çevreden, meslektaşlardan kaynaklanan birçok sorunla karşılaştıkları belirlenmiştir. İlaveten okuma alışkanlığı kazandırırken istenen sonuçlara ulaşabilmek için öğretmenlerin MEB yetkililerinden, meslektaşlarından ve ailelerden beklentileri ortaya konmuştur. Araştırma sonuçları doğrultusunda bazı önerilerde bulunulmuştur.

\section{A B S T R A C T}

This research is a qualitative case study which aims to determine the problems faced by primary school teachers, the strategies they used in having students acquire reading habits, and their opinions and suggestions about getting students acquire reading habits. In the research, easily accessible case sampling, one of the purposeful sampling methods, was used. 76 teachers working in state primary schools in 2018-2019 academic year participated in the study. The data were obtained through a semi-structured interview form. Four research questions were asked to obtain the data. The data were analyzed by content analysis method. As a result of the research, it was determined that teachers used many strategies that can be an example for their colleagues while having students acquire reading habits, and that they faced many problems arising from family, environment and colleagues. In addition, teachers' expectations from MoNE officials, colleagues and families have been established in order to achieve the desired results while getting students acqure reading habit. Some suggestions were made in line with the results of the research.

\section{Giriş}

Alışkanlık, "iç ve dış etkilerle hep aynı biçimde gerçekleşmesi beliren şartlanmış davranış" (TDK, 2019) olarak tanımlanmaktadır. Okuma alışkanlığı ise okumayı hayatı boyunca, sürekli ve düzenli kullanan ve bunu amaçlarına ulaşmada bir araç olarak gören kişilerin okuma eylemidir (Bayram, 1990). Başka bir tanıma göre ise okuma alışkanlığı temel okuma becerisini kazandıktan sonra bireyin okumaya şartlandırılması ve güdülenmesine bağlı olarak alışkanlığa dönüştürülmesidir (Gürcan, 1996). Okuma alışkanlığı, okumayı öğrendikten sonra bunu isteyerek, zevk alarak sürdürme eylemi biçiminde tanımlanabilir. Okuma alışkanlığı kazanmış birey;

\footnotetext{
*Bu çalışma 2019 yılında Samsun'da düzenlenen 19 Mayıs Üniversitesi Uluslararas1 100. Y1l Eğitim Sempozyumu'nda sözlü bildiri olarak sunulmuştur.

** Sorumlu yazar/Corresponding author

e-posta: ycelik@omu.edu.tr
} 
okuduklarını çevresindekilerle paylaşan, okudukları üzerinde düşünen, okuduklarını yorumlayabilen, okuduklarından öğrendiklerini hayatına yansıtabilen, okuyacağı materyali kendi kendine seçebilendir. Çocukta okuma alışkanlığının kazanılmasında çocuğun ilgisi, yeteneği, ailede okumaya yönelik tutum ve davranışlar ile çocuğa elverişli bir ortam oluşturulması gerekmektedir. Bunların yanında okul ve sınıf kütüphanelerinin işlevselliği, öğretmenlerin bu konudaki tutum ve davranışları, çevresel faktörler, kütüphanecilerin çocuklara yaklaşımı gibi birçok etken söz konusudur. (Çakmak ve Yılmaz, 2009; Jones, 1996). Öğretmenlerin öğrencilerine okuma alışkanlığını kazandırmak için değişik türde okuma araçlarını tanıtması ve bunları nasıl seçebileceklerini göstermesi ve uygun ortamlar sağlayarak okumalarını sağlaması gerekmektedir (Wilhelm, 1997).

Öğrencilere erken yaşlarda okuma alışkanlığı kazandırmanın onların geleceği açısından çok önemli bir adım olduğu herkesçe kabul edilen bir gerçektir. Bireyleri okuma alışkanlığına sahip ülkeler, bilim ve teknik alanında da önemli mesafeler kat etmişlerdir. Toplumda okuma alışkanlığı kazanma düzeyi bir bakıma gelişmişliğin göstergelerinden biridir (Yılmaz, 2012). Kişilerin okuma alışkanlığına sahip olduklarını söyleyebilmek için okumayı öğrendikten sonra okumaktan zevk alıyor olmaları gerekmektedir. Erken yaşlarda okuma alışkanlığı kazanmaları, çocukların sadece kelime hazinesi ve düşünme yeteneklerini artırmakla sınırlı kalmaz; yaratıcı zekâ, dinleme ve konuşma yeteneklerini de geliştirir. Aynı zamanda çocukların ruhsal, duygusal ve kişilik gelişimlerine de önemli bir katkıda bulunur. Bu bakımdan öğretmen ve aileler bu durumu dikkate alarak her şeyden evvel kendileri okuyarak model olmalı, kitap yazarları, kitaplar ve kitap seçimi üzerinde çocuklarıyla konuşmalıdırlar (Tanju, 2010).

Kitap okuma, belirli bir yaş ve zaman dilimine bağlı değildir. Bebeklik yaşlarında kitapların resimlerine ve okunan kitaplardaki kelimelerin seslendirilmesindeki ritim, okuma alışkanlığı için önemli bir başlangıç olarak görülebilir. Kitap okuma, çocukların kelime hazinesini geliştirmesinin yanı sıra yeni düşünceler üretmeleri açısından da önemli bir araçtır. Okumayan bireylerde bu özellikler gelişmemekte, var olanlar da gittikçe körelmektedir. Çocuğun okuma alışkanlığını kazanmasının ilk aşaması ailedir; anne ve babanın bu konudaki tutum ve davranışları kitap okumanın çocuk için önemli bir zevk halini alması açısından çok önemlidir. Bu bakımdan aile içinde kitaplarla vakit geçirme, kitap okuma, kitap üzerine konuşma, kitap seçme gibi etkinliklere çocukların katılımı sağlanmalıdır. Bu anlamda evde bir kitaplık oluşturulması, çocuklara oyuncaklarla birlikte kitap alınması önem arz etmektedir (Bus, \& Van IJendoorn, 1995; Yavuzer, 2012). İlkokul çağına gelinceye kadar çocuklar henüz okuma bilmediği için onlara albenisi olan çekici resimli kitaplar verilmelidir. Kitaplardaki resimler inceletilmeli, resimler üzerinde konuşturulmalı ve onlara vurgulu bir şekilde bu kitaplar ebeveynlerce okunmalıdır. $\mathrm{Bu}$ çalışmalar onlara okuma alışkanlığı kazandırma açısından önemli bir basamak olacaktır (Bus, \& Van IJzendoorn, 1995; Scarborough, \& Dobrich, 1994; Crain-Thoreson, \& Dale, 1992; Baker, Deborah, \& Kirsten, 1997; Dunning, Mason, \& Stewart, 1994; Lonigan, 1994).
Tanju’ya (2010) göre çocuklara kitap okuma alışkanlığı kazandırabilmek için şunlar yapılmalıdır: Küçük yaşlardan işe başlanmalı ve onlara model olunmalıdır. Evde okuma zamanları oluşturulmalı, okunan kitaplar üzerinde konuşulmalıdır. Kitabevleri ve kitap fuarlarına gezi düzenlenmelidir. Evde çocukların kendilerine ait bir kütüphane oluşturmaları özendirilmelidir. Lickteig ve Russell (1993) tarafından yapılan araştırmaya göre, öğretmenlerin çoğu öğrencilere sınıf ortamında öğle yemeğinden sonra en az 20 dakika yüksek sesle okuma çalışması yapmaktadırlar. Balcı (2003) tarafından yapılan çalışma sonucunda çocuklar için hazırlanan dergilerin her dönemde çocukların dikkatini çekmesinden dolayı okuma alışkanlığı kazanmalarında önemli bir katkı sağlamaktadır.

Okullarda çocuklara okuma alışkanlığı kazandırmayı yalnızca Türkçe derslerine ve Türkçe öğretmenlerine bırakmak doğru değildir. Okuma alışkanlığını kazandırma konusunda tüm dersler önemli olduğu için bu derslerin öğretmenleri sorumluluk almalıdır. Bir araştırmaya göre çocuklara kitap okuma alışkanlığı kazandırmada \% 70,7 oranla en büyük pay öğretmenlerde görülmektedir. Başka bir çalışmada ise bu oran \%53,7 olarak tespit edilmiştir (Arıc1, 2005). Öğrencilere ilk kitaplar \%33 oranla sınıf öğretmenleri tarafından verilmektedir. $\mathrm{Bu}$ bakımdan öğrencilere kitap okuma alışkanlığı kazandırabilmek için öncelikle öğretmenlerin iyi örnek olmaları gerekmektedir (Suna, 2006). Çocukların ve yetişkinlerin okuma alışkanlığını kazanmalarında birçok kaynaktan destek almalarının önemi çok büyüktür. Özellikle okuma alışkanlığının kazanılmasında bireyin bulunduğu toplumun değer sitemi ve ekonomik sistemi büyük bir öneme sahiptir. Bu bakımdan çocukların okuması ailece de desteklemeli ve çocuklar ödüllendirilmelidir. Çünkü okuma alışkanlığı kazanmak okumayı öğrenmekten daha zor bir davranıştır.

Okuma alışkanlığı, okunan yayın türü, okuma sıklığı, bir defada aralıksız okuma süresi, okuma zamanı, okunan kitabı elde etme yolu ve okumada takip edilen stratejilere göre değerlendirilir (Dökmen, 1994). Kişilerin okuma alışkanlığı kazanmadaki düzeyi bir yılda okudukları kitap sayısına göre belirlenir. Buna göre bir yılda en az 21 ve daha fazla kitap okuyan kişi çok okuyan, 6 ile 20 arasında kitap okuyanlar orta düzeyde, 5 ve daha az kitap okuyanlar ise az okuyanlar olarak sınıflandırılmaktadır (Maraşlı, 2005; Sağlamtunç, 1990; Staiğer, 1979). Bireylerin okuma yeteneği ve alışkanlığı arttıkça özsaygıları da artmaktadır. $\mathrm{Bu}$ nedenle okuma alışkanlığ 1 kazanma, bireylerin hayatında önemli bir yer tutmaktadır. Zaten Türkçe öğretiminin önemli amaçlarından birisi de öğrencilere okuma alışkanlığı ve zevki kazandırmaktır. Bu alışkanlığı ve zevki kazanan çocuklar gazete ve dergilerden, ulusal kültür ve sanat ile evrensel bilim değerini yansıtan eserlerden, çeşitli kitaplardan daha iyi yararlanabilirler (Calp, 2010, s. 93).

İlköğretim Türkçe Dersi Öğretim Programı'nda; öğrencilerin hayat boyu kullanabilecekleri dinleme/izleme, konuşma, okuma ve yazma ile ilgili dil becerilerini ve zihinsel becerileri kazanmaları, bu becerileri kullanarak kendilerini bireysel ve sosyal yönden geliştirmeleri, etkili iletişim kurmaları, Türkçe sevgisiyle, istek duyarak okuma ve yazma alışkanlığı edinmelerini sağlayacak şekilde bilgi, beceri ve değerleri içeren bir bütünlük içinde yapılandırıldı̆̆ $\breve{1}_{1}$ belirtilmiştir (MEB, 2018). 8-12 yaş 
döneminde çocukların her alanda bilgi sahibi olmaları, isteyerek ve bağımsız olarak okumaları amaçlanmaktadır. Ayrıca çocukların duygusal ve akademik gelişimlerine katkıda bulunmak amacıyla resimli ve bölümlü kitaplarla birlikte, bilgi içeren kitapları da yüksek sesle okumaları tavsiye edilmektedir (Jacobs, Marrison, \& Swinyard, 2000).

Ebeveynin tutumu, çocuğun okuma alışkanlığı konusunda önemli rol oynamaktadır. Okuma alışkanlığına sahip olan ebeveyn çocuğa küçük yaşlardan itibaren masal, öykü okuyarak, çocuğu kütüphaneye götürerek, kitaplar hediye ederek önemli katkıda bulunmaktadır. Kimi zamanda olumsuz davranışlar sergileyerek çocuğu farkında olmadan okumadan uzaklaştırabilmektedir (Sağlamtunç, 1989). Çocukların okuma alışkanlığı kazanamamasında en önemli etkenlerden birisi nitelikli kitaplarla tanıştırılmamış olmasıdır. Bu konuda yazarların şairlerin yanı sıra gazete, radyo ve televizyon kuruluşlarına ve kitabevlerine önemli görevler düşmektedir. 3., 4. ve 5. sınıf öğrencileri üzerinde yapılan bir çalışmada çok okuyan çocukların okumayı da çok sevdikleri, okula başlamadan ailelerinin kendilerine kitap okuduğu, kendilerine ait kitaplık oluşturdukları ve öğretmenlerle öğrenciler arasında okunan kitaplar üzerinde tartışmalar yapıldığını tespit etmişlerdir. Ayrıca, ailenin eğitim düzeyi ile okuma alışkanlığı kazanmaları arasında pozitif yönde ilişki bulunmuştur (Olcay, 1990). Gönen, Öncü ve Işıtan (2004) yaptıkları araştırmada çocukların okudukları kitap üzerinde tartışmaktan hoşlandıklarını ortaya koymuştur. Sever ve diğerleri (2013) ise 4. sınıf öğrencileri üzerinde yaptıkları araştırma sonucunda, çocukların okuma kültürü düzeyinin artması ile televizyon, bilgisayar ve internete ayırdıkları zamanın azaldığını tespit etmişlerdir.

Aksoy ve Öztürk'ün (2018) yaptığı bir araştırmaya göre, öğrencilerin belirli bir okuma alışkanlığına sahip oldukları, öğretmenlerin de öğrencilerinde okuma alışkanlığ kazandırmak için gerekli çalışmalar yaptıkları ancak kitaplıklardaki yayın türlerinin çok çeşitli olmaması sebebiyle öğrencilerin sınıf kitaplıklarından yeterince yararlanmadıkları ve televizyon izlemeyi ve bilgisayar oyunlarını okumaya tercih ettikleri tespit edilmiştir. Başka bir araştırmaya göre (EARGED, 2007) ailelerin kitap alma ve okumayı bir ihtiyaç olarak görmediği, boş zamanlarını kitap okuyarak değerlendiren öğrenci sayısının çok az olduğu, öğrencilerin kitap sahibi olmaya istekli olmadıkları ve 13-14 yaşlarından sonra kitap okumaya başladıkları tespit edilmiştir.

Devrimci’nin (1993) 5. sınıf öğrencileri üzerinde yaptığı araştırmada okuma alışkanlığı kazanmada sosyo-ekonomik durum ve cinsiyetin etkili olmadığı tespit edilmiştir. Diğer bir araştırmaya göre de anne ve babaların çocuk kitaplarını tanıma, seçme konusundaki bilgileri çocuklarının okuma alışkanlığı kazanması konusunda önemli bir faktör olarak görülmüştür (Gürler, 1999). Gudakovska'nın (1996) Litvanya'daki çocukların okuma alışkanlıklarını belirlemek amacıyla 5.-7. sınıf öğrencileri üzerinde yaptığı çalışma sonucunda öğrencilerin sırasıyla en çok bilim kurgu, dedektif hikâyeleri, masallar ve tarihi roman türlerini okudukları ve öğrencilerin kitap seçimlerini en çok ailelerinin etkilediği, bunu arkadaşları radyo-televizyon ve öğretmenlerin izlediği tespit edilmiştir.

Türkiye İstatistik Kurumu'nun (TÜİK) yaptığı araştırmaya göre Türkiye'de bir günde televizyon izlemeye harcanan süre 6 saat, internet kullanımına harcanan süre 3 saat, kitap okumaya ayrılan süre ise 1 dakika olarak tespit edilmiştir. Aynı araştırmaya göre, Avrupa'da ortalama kitap okuma oranı \% 21 iken Türkiye'de bu oran \% 0,1 olarak tespit edilmiştir (Bugün, 2014). Okur-yazar sayısının düşük olmas1, okumaya yeterince ihtiyaç duymama, televizyon izlemeye fazla zaman ayırma, ailede okumaya karşı motivasyonun az olması ve izlenen eğitim politikalardan kaynaklanan sebeplerle Türkiye'de okuma alışkanlığı istenilen düzeyde gelişememiştir (Özgen, 1992). Türkiye'de basılan, satılan dergi, kitap ve gazete sayıları da bu durumu teyit eder (Özen, 2001). Birçok kişi, zaman zaman okuma alışkanlığı kazanma konusundaki eksikliklerimizi değişik yollarla dile getirmektedirler. Özellikle Batı ülkelerine gidenler okuma alışkanlığı konusundaki eksikliklerimizden çeşitli platformlarda söz etmekte ve bu durumdan yakınmaktadırlar. Otobüs ve trenlerde yolculuk yaparken bizim vatandaşlarımız dışındakilerin kısa bile olsa yolculuk süresini kitap okuyarak değerlendirdikleri vurgulanmaktadır. Kişilerin bu alışkanlıklarını parkta, bahçede, deniz kenarında, yemekhanede ve her boş vakitlerinde sürdürdükleri belirtilmektedir.

İlkokul öğretmenleri, ilköğretimde görev yapan branş öğretmenleri ve ortaöğretim öğretmenlerinin okuma alışkanlıkları üzerine yapılan bir araştırmada "Yeterince okuduğunuzu düşünüyor musunuz?" sorusuna öğretmenlerin \% 53,2 “k1smen”, \% 31,1 "hayır" ve \% 15,7'i “evet” cevabını vermişlerdir (Karaşahin, 2009). Problemin çözümü noktasında zaman zaman bazı çalışmalar yapılmasına rağmen halen iyi bir noktaya gelindiği söylenemez. $\mathrm{Bu}$ çalışmaların tek boyutlu yürütülmesi elbette istenen sonucu vermez. Sorunun çözümünde aileye, okula-öğretmene; kitle iletişim araçlarına yayıncılara-kitap satıcılarına; yerel yönetimlere, akademisyenlere, tasarımcılara ve çocuk kitabı yazarlarına pek çok görev düşmektedir (Akbayır, 2009).

Önceden de belirtildiği gibi okuma alışkanlığı kazandırma konusunda en büyük görev her derece ve türdeki okullarda görev yapan öğretmenlere düşmektedir. Öğretmenler arasında en büyük sorumluluk ise ilkokul öğretmenlerindedir. $\mathrm{Bu}$ sebeple önce ilkokul öğretmenlerinin bu konudaki birikimlerini, yaptıkları uygulamaları, karşılaştıkları sorunları ve çözüme yönelik önerilerini tespit etme, sonra da paylaşmanın problemin çözümüne katkı sağlayacağı düşünülmektedir. Öğretmenlerin bu konuda edindikleri tecrübeleri, sorunlara yönelik çözümlerini ve önerilerini konu alan ilkokul düzeyinde sınırlı sayıda araştırma vardır. $\mathrm{Bu}$ araştırmanın da okuma alışkanlığı kazandırma konusunda alana bir katkı sağlaması beklenmektedir.

\section{Yöntem ve Uygulama}

Bu bölümde araştırma modelinden, çalışma grubundan, veri toplama aracindan, verilerin toplanmasından ve verilerin analizinden bahsedilmektedir.

\subsection{Araştırma Modeli}

$\mathrm{Bu}$ araştırma; ilkokul öğretmenlerinin okuma alışkanlığ konusunda kazandıkları deneyimleri, yaşadıkları sorunları, bu konuyla ilgili görüş ve önerilerini ve ilgililerden beklentilerini tespit etmek amacıyla yapılmış durum 
çalışması deseninde nitel bir çalışmadır. Çalışmada okuma alışkanlığının kazandırılmasına ilişkin öğretmen görüşleri değişik yönlerden ele alınarak incelenmiştir. Durum çalışması "nasıll" ve "niçin" soruları temele alınarak, araştırmacı tarafından kontrol edilemeyen olgu ya da olayların derinliğine incelenmesine ve olgu ya da olaylarla ilgili tespitlerde bulunmaya dayanan araştırma yöntemidir (Yıldırım ve Şimşek, 2011).

\section{2. Çalışma Grubu}

$\mathrm{Bu}$ araştırma, 2018-2019 eğitim-öğretim yılında, resmi ilkokullarda sınıf öğretmenliği yapan 76 öğretmenle gerçekleştirilmiştir. Araştırmada amaçlı örnekleme yöntemlerinden kolay ulaşılabilir durum örneklemesi kullanılmıştır. Bu örnekleme yöntemi, varlığından emin olunduğu halde kolay ve hızlı ulaşılamayan unsurlar için kullanılır. Çoğu kez nitel araştırmalarda kullanılan örneklem büyüklüğünün genelleme yapmaya uygun olmadığı düşüncesinden hareketle, çalışılması kolay ve pahalı olmayan durumlar tercih edilmektedir (Patton, 2005; Vogt, \& diğerleri, 2012; Yıldırım ve Şimşek, 2011). Araştırmanın amacına hizmet etmesi bakımından farklı okullarda (bağımsız ve birleştirilmiş sınıflı) ve farklı şartlarda (köy ve şehir merkezi) görev yapan öğretmenlerin araştırmaya katılmaları sağlanmıştır. Araştırmaya katılan öğretmenlerin 62'si bağımsız sınıflı 14'ü ise birleştirilmiş sinıflı okullarda görev yapmaktadır.

\subsection{Veri Toplama Arac1}

Araştırma verilerini elde etmek için açık uçlu sorulardan oluşan bir form hazırlanmasına karar verilmiștir. Form hazırlanmadan önce alanla ilgili kaynaklar (Güngördü, 2006; Calp, 2010; Sever ve diğerleri., 2013; Aksoy ve Öztürk, 2018) incelenerek bir soru havuzu olușturulmuştur. Havuzdaki sorular, Türkçe alanında iki ve eğitim bilimleri alanında üç olmak üzere beş akademisyen tarafından incelenmiş ve onların önerileri doğrultusunda gerekli düzenlemeler yapılmıştır. Türkçe alanındaki uzmanlar soruları anlaşılırlık ve kapsam yönünden değerlendirerek gerekli düzeltmeleri yapmışlardır. Eğitim bilimleri alanındaki uzmanlar ise araştırma teknikleri ve anlaşılırlık yönünden gerekli düzeltmeleri yapmışlardır. Uzmanların önerileri doğrultusunda altı olan soru sayısı ortak noktalarından hareketle birleştirilerek dörde düşürülmüştür. Ayrıca soruların ifade biçimleri kısaltılarak anlaşıılması kolaylaştırılmıştır. Elde edilen bu sorular üç öğretmene uygulanmıştır. Uygulama sırasında anlaşılmasında ve ifade biçiminde sıkıntı olan bazı cümlelerde küçük değişiklikler yapılmıştır. Böylece soruların anlaşılırlığı konusundaki tereddütler giderilerek dört soruluk bir görüşme formu oluşturulmuştur. Formdaki sorular şunlardır:

1-İlkokul birinci sınıftan itibaren okuma alışkanlığı kazandırmak amacıyla izlediğiniz stratejilere değinir misiniz?

2-Okuma alışkanlığı kazandırma konusunda karşılaştığınız sorunlardan bahseder misiniz?

3-Okuma alışkanlığı kazandırılması konusunda önerileriniz nelerdir?
4-Okuma alıșkanlığı kazandırma konusunda MEB, Milli Eğitim Müdürlüğü, okul müdürlüğü ve velilerden ne tür katkılar beklersiniz?

Nitel araştırmalarda güvenirlik, veriler üzerinde birden çok araştırmacının verdiği kodlar arasındaki kararlılık olarak anlaşılmaktadır (Creswell, 2013). Araştırmacılar arasındaki tutarlılığ soruyla ilgili yaptıkları kodlamalar karşılaştırılarak görüş birliği ve görüş ayrılığı şeklinde düzenlenmiştir. Bu bağlamda, araştırmacıların birbirlerine oldukça yakın anlamda kullandıkları kodlar görüş birliği; anlam itibariyle birbirine benzemeyen veya benzerliğine karar vermekte tereddüt edilen kodlar ise görüş ayrılığ edilmiştir. Üzerinde görüş ayrığı olan kodlara araştırmada yer verilmemiştir. Daha sonra sorulara verilen cevaplarla ilgili uyuşum yüzdesi (Uyuşum yüzdesi (Güvenirlik) = Görüş birliği / (Görüş Birliği + Görüş Ayrılığı) x 100) formülü kullanılarak hesaplanmıştır (Miles \& Huberman, 1994). Uyuşum Yüzdesi (Güvenirlik) = 161/ $(161+33) .100$ işleminden uyuşum yüzdeleri yaklaşık 0,83 olarak tespit edilmiştir. Uyuşum yüzdesinin 0,70 'ten yüksek çıkması yeterli olarak kabul edilmektedir (Yıldırım ve Şimşek, 2011).

\subsection{Verilerin Toplanmas1}

$\mathrm{Bu}$ araştırmada veriler araştırmacı tarafından geliştirilen yarı yapılandırılmış, dört sorudan oluşan bir görüşme formu ile toplanmıştır. Açık uçlu sorular araştırmacıya bir yandan araştırma konusuyla ilgili esneklik kazandırırken, diğer taraftan da konu ile ilgili önemli değişkenlerin dikkatten kaçmasını engeller (Yıldırım ve Şimşek, 2011).

Veriler 2018-2019 öğretim yılında resmi ilkokullarda görev yapan öğretmenlerden elde edilmiştir. Soru formu istekli katılımcılara yeterli süre verilerek cevaplamaları istenmiştir. Uygulama bizzat araştırmacının kontrolünde yapılmış olup, anlaşılmayan noktaların araştırmacıya sorulması konusunda gerekli bilgilendirme yapılmıştır. Katılımcıların soruları yönlendirme olmaksızın cevaplamaları sağlanmıştır.

\subsection{Verilerin Analizi}

$\mathrm{Bu}$ çalışmada, içerik analizi teknikleri kullanılmıştır. Bu bağlamda öncelikle tarama ölçütleri belirlenmiş ve bu ölçütlere göre kodlamalar yapılarak bazı temalara ulaşılmış, daha sonra temalar alt tema ve kategorilere ayrılmıştır. Kodlama çalışmaları araştırmacının dışında nitel araştırma konusunda deneyimli başka bir araştırmacı tarafından da yapılmıştır. Araştırmacılar birbirinden bağımsız çalışmışlardır. Ayrıca bireylerin görüşlerini çarpıcı bir biçimde yansıtabilmek amacıyla doğrudan alıntılara yer verilmiştir. Öğretmenler araştırmada Ö1, Ö2, Ö3...şeklinde kodlanmıştır. İçerik analizinde temelde yapılan işlem, birbirine benzeyen verileri belirli kavramlar ve temalar çerçevesinde bir araya getirmek ve bunları okuyucunun anlayabileceği bir biçimde organize ederek yorumlamaktır. İçerik analizi, üzerinde çalışılan metnin belirli kurallara göre kodlanarak daha küçük bilgi kategorileri halinde sistematik ve yinelenebilir bir şekilde özetlenmesine dayalı teknik olarak tanımlanabilir (Büyüköztürk ve diğerleri., 2008; Cohen, Manion, \& Morrison 2007; Yıldırım ve Şimşek, 2011). 


\section{Bulgular ve Yorumlar}

Araştırmaya katılan öğretmenlerin öğrencilere okuma alışkanlığı kazandırmada takip ettikleri stratejilerle ilgili görüşleri Tablo 1'de sunulmuştur.

Tablo 1. Okuma Alışkanlığı Kazandırmada Takip Edilen Stratejiler

\begin{tabular}{|c|c|}
\hline \multicolumn{2}{|c|}{$\begin{array}{c}\text { Öğretmenlerin okuma alışkanlığı kazandırmada takip ettikleri } \\
\text { stratejiler }\end{array}$} \\
\hline \multicolumn{2}{|c|}{ Sınıf içinde } \\
\hline $\begin{array}{l}\text { Motivasyon kazandırma ile } \\
\text { ilgili }\end{array}$ & Uygulama ile ilgili \\
\hline $\begin{array}{l}\text { *Sınıf kitaplığı için canlı, } \\
\text { çekici kitaplar seçme } \\
\text { *En çok kitap okuyanı ayın } \\
\text { kitap kurdu seçe } \\
\text { *Ödüllendirmek } \\
\text { *Tatilde okuyanlarla ilgili } \\
\text { görseller sunma } \\
\text { *Okurken mutlu olan çocuk } \\
\text { resimleri gösterme } \\
\text { *Bitirilen kitap için sticker } \\
\text { ödül yapıştırma. } \\
\text { *Kitap hediye etme } \\
\text { *Okuma sırasında tütsü } \\
\text { yakarak enstrüman dinletme } \\
\text { *Kitap ve yazar tanıtımı } \\
\text { yapma } \\
\text { *Kütüphaneye götürme } \\
\end{array}$ & $\begin{array}{l}\text { *Kendilerinin getirdikleri kitapları } \\
\text { sınıfta okutup anlattırma } \\
\text { *Okunanları dramatize ettirme } \\
\text { *Okunan kitapların } \\
\text { kahramanlarından pano oluşturma } \\
\text { *Ailesiyle kitap okuduğu } \\
\text { zamanları işaretleme } \\
\text { *Okudukları kitaplardan } \\
\text { etkilendikleri bilgileri paylaşma } \\
\text { *Kitapta anlatılanların resmini } \\
\text { yaptırma } \\
\text { *Sevdikleri öyküleri sesli okuma } \\
\text { *Okunan kitaplarla ilgili liste } \\
\text { tutma } \\
\text { *Görsellere bakarak hikâye yazma } \\
\text { *Hikâye haritası oluşturma } \\
\text { *Sınıf panosunda yazarları ve }\end{array}$ \\
\hline Sinıf dişında & eserlerini tanitma \\
\hline $\begin{array}{l}\text { *Kitap fuarlarına katılma } \\
\text { *Yazarlarla sohbete } \\
\text { götürme } \\
\text { *Değişik mekanlarda } \\
\text { okuma } \\
\text { *Veli ile iş birliği kurma } \\
\text { *Veli duyarlılı̆ını artırma } \\
\text { *Birlikte kitapçıya giderek } \\
\text { okuyacağı kitabı seçme } \\
\text { *Güzel havalarda dişarıda, } \\
\text { huzurlu ortamda okuma }\end{array}$ & $\begin{array}{l}\text { *Okunan hikâyenin sonunu } \\
\text { buldurma } \\
\text { *Okunan kitaplar üzerinde } \\
\text { konuşma } \\
\text { *Kısa metinler ve kafiyeli şiirler } \\
\text { okutma } \\
\text { *Okunan kitaplarla ilgili özet } \\
\text { yaptırma } \\
\text { *Haftada bir dersi kitap okumaya } \\
\text { ayırma } \\
\text { *Öğrencilerin ilgi ve isteğine göre } \\
\text { okuma programı hazırlama }\end{array}$ \\
\hline Evde & *Okumaya başlamadan önce \\
\hline $\begin{array}{l}\text { *Evde aile üyeleriyle } \\
\text { birlikte okuma saati } \\
\text { düzenleme }\end{array}$ & $\begin{array}{l}\text { resimler üzerinde konuşma } \\
\text { *Yarıya kadar okunan hikayeleri } \\
\text { tamamlatma } \\
\text { *Okuma yarışları düzenleme } \\
\text { *Kendisi okuyarak model olma } \\
\text { *Okumaya resimli ve az yazılı } \\
\text { kitaplarla başlama } \\
\text { *Çocukların okuma hızına uygun } \\
\text { kitap takip etme }\end{array}$ \\
\hline
\end{tabular}

Öğretmenlerin okuma alışkanlığı kazandırmada takip etikleri stratejilerle ilgili görüşleri analiz edilerek önce üç temaya ayrılmıştır. Temalar, okul içinde, evde ve okul dışında kullanılan stratejiler olarak ele alınmış; okul içinde izlenilen stratejiler de motivasyon kazandırmaya yönelik olanlar ve uygulamaya yönelik olanlar olmak üzere iki alt kategori altında düzenlenmiş ve bunlar da alt kategorilere ayrılarak Tablo 1'de gösterilmiştir.

Sınıf içinde motivasyon kazandırmaya yönelik olarak öğretmenlerin çoğunluğu çok kitap okuyan öğrencileri ödüllendirdiklerini vurgularken; bazıları sınıf kitaplığı için canlı, çekici kitaplar seçmek, kütüphaneye götürmek gibi aktiviteleri gerçekleştirdiklerini belirtmişledir. Öğretmenlerin yaptıkları uygulamalarla ilgili ifadelerinden bazıları aşağıda aynen gösterilmiştir.

Ö.1 “......... Stnıf kitaplığı için seçtiğim kitapların baskılarının canlı, çekici ve renkli olmasına özen gösteriyorum. Tuttuğum sinıf listesine göre her ay en çok kitap okuyan ögrencisini ayın kitap kurdu seçerek rozetle ödüllendiriyorum."

Ö.25. "Birinci sınıfta masal ve hikâye okuyarak ve hikayedeki kahramanların canlandırarak okumaya karşı ilgi uyandırlyorum.... Hikâyeleri okurken kendilerini hikâyenin kahramanı yerine koymalarını sağlıyorum."

Öğretmenlerin sınıf içinde öğrencilere okuma alışkanlığı kazandırırken uygulamaya dönük takip ettikleri stratejilerden en çok ögrencilere okuduklarını dramatize ettirme vurgulandı. Bunu sırasıyla çocukların getirdikleri kitapları sınıfta okutup çocuklara anlattırma, okunan kitaplar üzerinde çocukları konuşma, okumaya başlamadan önce çocuklarla resimler üzerinde konuşma, görsellere bakarak hikâye yazma, okunan hikâyenin sonunu buldurma, hikâye haritası oluşturma, kitapta anlatılanların resmini yaptırma, çocukların ilgi ve isteğine göre okuma programı hazırlama, yarıya kadar okunan hikâyeleri tamamlatma ve okumaya resimli ve az yazılı kitapla başlama stratejileri takip etmektedir. Öğretmenlerin yaptıkları uygulamalarla ilgili ifadelerinden birisi aşağıda aynen gösterilmiştir.

Ö.47. "Birinci sinıftan itibaren dinleme alışkanliğl ve görselleri yorumlama alışkanlığı kazandırıyorum. Onların dikkatini çekecek kısa şiir, fikra, hikâyeler okurum; yarım birakıp tamamlatırım, böylece dikkati çekerim. Dikkat çekici masal ve hikâyeler seçerim. Onları okurken can alıcı yerinde keserim, sonraki gün devam ederim. Okuma ögrenilmişse, yazarak tamamlatırım. Okumaya geçilmişse sözlü tamamlatırım."

Öğretmenlerin öğrencilere okuma alışkanlığı kazandırırken uygulamaya dönük sınıf dişında takip ettikleri stratejilerden, en çok değişik mekânlarda okuma vurgulanırken, bunu kitap fuarlarına katılma, yazarlarla sohbete götürme ve birlikte kitapçıya giderek okuyacağı kitabı seçme stratejileri takip etmektedir. Öğretmenlerin yaptıkları uygulamalarla ilgili ifadelerinden biri aşağıda aynen gösterilmiştir.

Ö.6. “Kitap fuarına götürüyorum. Okudukları kitaplardan, etkilendikleri bilgileri paylaştıkları etkinlikler yapıyorum. ... Aileleri ile kitapçıdan kitap alma etkinlikleri yapıyorum."

Öğretmenlerin evde öğrencilere okuma alışkanlığı kazandırırken izlediği strateji, evde aile üyeleriyle birlikte okuma saati düzenleme olarak analiz edilmiştir. Öğretmenlerin yaptıkları uygulamalarla ilgili ifadelerinden biri aşağıda aynen gösterilmiştir.

Ö.59. "Velilerimden çantalarında çocuk kitabı taşımalarını istiyorum. Çocuğuyla durakta, tramvayda vb. yerlerde birlikte kısa okumalar yapmasinı istiyorum. Evde 15-20 dk. okuma saati (ailece) yapmaların tavsiye ediyorum."

Araştırmaya katılan öğretmenlerin öğrencilere okuma alışkanlığı kazandırırken karşılaştıkları sorunlarla ilgili görüşleri, Tablo 2'de sunulmuştur. 
Tablo 2. Okuma Alışkanlığı Kazandırırken Karşılaşılan Sorunlar ile İlgili Öğretmen Görüşleri

\begin{tabular}{|c|c|}
\hline \multicolumn{2}{|c|}{ Okuma alışkanlığı kazandırırken karşılaşılan sorunlar } \\
\hline Aileden kaynaklanan sorunlar & $\begin{array}{c}\text { Öğrenciden kaynaklanan } \\
\text { sorunlar }\end{array}$ \\
\hline $\begin{array}{l}\text { *Aile desteği sağlayamama } \\
\text { *Ailede okuma alışkanlığı } \\
\text { olmaması } \\
\text { *Evde bu amaçla bir gayret } \\
\text { olmaması } \\
\text { *Sevmedikleri halde evde } \\
\text { ablaların ve ağabeylerin } \\
\text { kitaplarını okumaları yönünde } \\
\text { baskı yapılması } \\
\text { *Ailelerin direnç göstermesi } \\
\text { *Çocuklara okumak istemedikleri } \\
\text { kitapları okutma } \\
\text { *Maddi imkansılılktan dolayı } \\
\text { kitaba para ayrılamaması } \\
\text { *Çocukların ayrı odalarının } \\
\text { olmaması TV'nin bulunduğu } \\
\text { odada oturulması } \\
\text { *Velilerin aceleci davranmaları } \\
\text { *Aile içi sorunların çocuklara } \\
\text { yansıltılması }\end{array}$ & $\begin{array}{l}\text { *Noktalama işaretlerine } \\
\text { dikkat etmediği için } \\
\text { okuduğunu anlamama } \\
\text { *Okumadığı halde } \\
\text { okuduğunu söyleme } \\
\text { *Okuması yavaş olan } \\
\text { öğrencilerin direnç } \\
\text { göstermesi } \\
\text { *Okuma istememe, } \\
\text { okumadan sıkılma } \\
\text { *Devamsılık yapma }\end{array}$ \\
\hline $\begin{array}{l}\text { Okuldan (ögretmenden) } \\
\text { kaynaklanan sorunlar }\end{array}$ & $\begin{array}{l}\text { Çevreden kaynaklanan } \\
\text { sorunlar }\end{array}$ \\
\hline $\begin{array}{l}\text { *Çocuğun yaşına, ilgi alanına } \\
\text { uygun olmayan kitapları } \\
\text { okumaya zorlanması } \\
\text { *Okulda okuma saatlerinin sınırlı } \\
\text { olması }\end{array}$ & $\begin{array}{l}\text { *TV ve cep telefonlarındaki } \\
\text { oyunlara odaklanma } \\
\text { *Okuyan insanlara gereken } \\
\text { önemin verilmemesi } \\
\text { *Okuma ile ilgili bazı } \\
\text { çabaların göstermelik olması } \\
\text { *İnternet ve sanal ortamın } \\
\text { ilgilerini çekmesi sanal } \\
\text { ortamda çok vakit geçirme }\end{array}$ \\
\hline
\end{tabular}

Öğretmenlerin okuma alışkanlığı kazandırırken karşılaştıkları sorunlarla ilgili görüşleri analiz edilerek dört temaya ayrılmıştır. Temalar, aileden kaynaklanan, öğretmenden kaynaklanan, öğrenciden kaynaklanan ve çevreden kaynaklanan sorunlar olarak ele alınmıştır. Bunlar daha sonra alt temalara ayrılarak Tablo 2'de gösterilmiştir.

Aileden kaynaklanan sorunlardan en çok "aile desteği sağlayamama" vurgulanırken bunu "ailede okuma alışkanlığı olmaması, sevmedikleri halde evde abla ve ağabeylerinin kitaplarını okumaları yönünde baskı yapılması, çocuklara okumak istemedikleri kitapları okutma, maddi imkânsızlıktan dolayı kitaba para ayrılamaması, çocukların ayrı odalarının olmaması TV'nin bulunduğu odada oturulması, aile içi sorunların çocuklara yansıtılması gibi sorunlar takip etmektedir. Öğretmenlerin karşılaştıkları sorunlarla ilgili ifadelerden biri aşağıda aynen gösterilmiştir.

Ö.1. “...Çocuklardan aldığım en önemli şikâyet ise, onlara evdeki abla ve ağabeylerinin kitaplarını okumaları yönünde baskı yapılıp, sevdikleri, dikkatlerinin çeken kitapları tedarik etmelerinin engellemesi."

Okuldan (öğretmenden) kaynaklanan sorunlar, "çocuğun yaşına, ilgi alanına uygun olmayan kitapları okumaya zorlanması, okulda okuma saatlerinin sinırlı olması" olarak analiz edilmiştir. Öğretmenlerin bu konuda karşılaştıkları sorunlarla ilgili ifadelerden biri aşağıda aynen gösterilmiştir.

Ö.13. “...bazen ögretmenlerin ve velilerin zorlayıc yaklaşımı yaşına, ilgi alanına göre belirlenmeyen kitap seçimlerinin çocuklara olumsuz yansıdığını düşünüyorum.",

Öğrenciden kaynaklanan sorunlardan en çok "okuması yavaş olan öğrencilerin direnç göstermesi” vurgulanırken, bunu "noktalama işaretlerine dikkat etmediği için okuduğunu anlamama, okumadığı halde okuduğunu söyleme, okumak istememe, okumaktan sıkılma, devamsızlık yapma" gibi sorunlar takip etmektedir. Öğretmenlerin bu konuda karşılaştıkları sorunlarla ilgili ifadelerden biri aşağıda aynen gösterilmiştir.

Ö.25. “Uzun süre okumak istemiyorlar, sıkllyyorlar. ...Okuma hızları yavaş olan öğrenciler okuduklarını anlamadıkları için okumak istemiyorlar."

Öğretmenler çevre ile ilgili karşılaştıkları sorunlardan en çok “internet ve sanal ortamın öğrencilerin ilgilerini çekmesi, sanal ortamda çok vakit geçirmeyi vurgulanmıştır. Öğretmenlerin bu konuda karşılaştıkları sorunlarla ilgili ifadelerinden biri aşağıda aynen gösterilmiştir.

Ö.12. "Internet ve sanal alem çocuklarl okumaktan men ediyor, soğutuyor."

Araştırmaya katılan öğretmenlerin öğrencilere okuma alışkanlığı kazandırma konusundaki önerileri, tablo 3 'te sunulmuştur

Tablo 3. Öğretmenlerin Okuma Alışkanlığı Kazandırma Konusundaki Önerileri

\begin{tabular}{ll}
\hline & Öneriler \\
\hline Aileye yönelik öneriler & Okula (öğretmene-meslektaşlara) \\
yönelik öneriler \\
\hline *Evde kitap, gazete, dergi & *Öğrencilerle birebir ilgilenme \\
vs. okuyarak çocuklarına & *Evde okuma saati düzenleme \\
örnek olma & *Gülen yüzlerle, yıldızlarla teşvik \\
*Kitap okuma mekanında & etme \\
uyarıcılar bulundurmama & *Aileleri bilinçlendirme ve işbirliği \\
*Aile üyeleri ve öğretmen & yapma \\
birlikte toplu okuma & *Velilerinde katılımıyla \\
saatleri düzenleme & kütüphaneye giderek kitap okuma \\
*Teknolojik araçların & *Küçük hikaye ve masal yazma \\
kullanımını kısıtlama & denemeleri yaptırma \\
*Yatmadan önce 1 saat & *İlginç ve ilgi çekici hikayelerle \\
kitap okumasını sağlama & kitaplı̆ı zenginleştirme \\
*Okurken çekilmiş & *Güncel öyküleri okuma \\
fotoğrafları paylaşma & *Filmi yapılmış makaleleri önce \\
*Haftada 2-3 defa okula & okutup sonra izletme, canlandırma \\
gelerek çocukla birlikte & *Bitirdikleri kitabı resimle \\
okuma & anlattırma \\
*Evde çocuğa sesli kitap & *Her ay bir kitap almalarını isteme \\
okuma & *Öğrencilerin evde kendilerine ait \\
\cline { 1 - 2 } Öğrenciye Yönelik & kitaplık oluşturmalarını sağlama \\
Öneriler & *Öğrencilere güzel şiirler, \\
\hline *Kendi kütüphanesindeki & tekerlemeler ve bilmeceler okuma. \\
kitapları ödünç verme & *Masal okuma ve ana fikrini \\
*Günün planlanan bir & buldurma \\
saatinde aksatmadan & *Okuma-yazma eğitiminin çeşitli \\
okuma yapma & oyun materyalleriyle \\
*Gece yatarken kitap & zenginleştirilmesi \\
okuma resimlerini & *Veli ve öğretmen tarafindan \\
paylaşma & incelenen okuma takip çizelgeleri \\
*Öğrendiği bilgilerin & tutma \\
kitabının adını söyleme & *En çok kitap okuyanları \\
\hline &
\end{tabular}




\begin{tabular}{ll}
\hline *Sevdikleri kahramanların & ödüllendirme \\
bulunduğu kitapları seçip & *Her okudukları kitap için Türkiye \\
okuma & haritasından bir ili boyatma \\
*Günlük uyumadan önce & *Kazanarak aldıkları kitapları \\
15 dakika kitap okuma & okutma \\
*Okuduklarını öğretmenle & *Evde okudukları hikayelerin \\
paylaşma. & özetini sınıfta anlattırma \\
*Ev ziyaretleri yaparak & *Kuklalardan yararlanma \\
birlikte okuma & *Okuma balonları kullanma \\
*Sınıfta sesli okuma yapma & *Hikaye haritası yapma \\
(öykü, şiir) & *Masal sonu tamamlama yapma \\
*Şiirler ezberletme & *Seviyelerine uygun kitap seçimi \\
*Sınıf kitaplığını & yapma \\
zenginleştirme & *Ödül olarak kitap hediye etme \\
\hline Okuma materyallerine & *Okumayı özendirici çocuk \\
yönelik öneriler & oyunları düzenlenme \\
\hline *Kitapların sonunda hikaye & *Velilerle birlikte kitap okuma \\
ile ilgili etkinlikler, & *Veliyi teşvik etmek için teşekkür \\
bilmeceler, resim boyama & yazma \\
vs. etkinlikler olmalı & *Okunan hikayeyi parmak kukla ile \\
*Harf puntoları & canlandırma \\
öğrencilerin yaşına uygun & *Sınıf kitaplığını güncel kitaplarla \\
olmalı & zenginleştirme \\
*Çocukların dünyasına & *Sınıfta okuma köşeleri oluşturma \\
hitap etmeli. & *Öğrencilere rol model olma \\
*Sayfa sayısı fazla & *Okunan kitaplar üzerinde \\
olmamalı & konuşma, sohbet etme. \\
*Resim, yazı ve sağlamlık & *Okuma panosu yapılarak \\
yönünden iyi olmalı & sembolik ödüllendirme yapma \\
& *Sınıfta velilerin okuyacakları \\
& kitaplar bulundurma \\
& *Aldı̆ı kitapları çocuklara tanıtma \\
& *Projektörle perdeye yansıtılan \\
& küçük okuma parçaları okuma \\
\hline & \\
&
\end{tabular}

Öğretmenlerin okuma alışkanlığı kazandırma ile ilgili önerileri “aileye yönelik öneriler, okula (öğretmene) yönelik öneriler, öğrenciye yönelik öneriler ve okuma materyallerine yönelik öneriler" olmak üzere önce 4 temaya, bu temalar da kendi içinde alt temalara ayrılarak Tablo 3'te gösterilmiştir. Tablo 3'e bakıldığında öğretmenlerin aileye yönelik önerileri içinde en çok "velilerin evde kitap, gazete, dergi vs. okuyarak örnek olması" ve kitap okuma mekânında uyarıcılar bulundurmama" önerisi vurgulanmaktadır. Öğretmenlerin bu konudaki önerilerinden biri aşağıda aynen gösterilmiştir

Ö.6. "Veliler kitap okuma konusunda çocuklarına örnek olmalıdır. Hediye kitap alabilirler. Kitapçılara, kitap fuarlarına götürebilirler. Kitaplar hakkında konuşabilirler (Ortak okudukları kitap vb.)."

Öğretmenlerin meslektaşlarına yönelik önerilerine bakıldığında en çok "öğretmen, öğrenci, veli birlikte kitap okuma, öğrencilere rol model olma"nın vurgulandığ görülmektedir. Öğretmenlerin öğrencilere okuma alışkanlığı kazandırma ile ilgili meslektaşlarına yönelik önerilerinden biri aşağıda aynen gösterilmiştir.

Ö.13."...Yazarlarla tanışması sağlanarak, yazarların hayatlarından örnek verilerek bağlılık duygusu oluşturulmall. Öğrencilere kütüphane deneyimi yaşatmall. Popüler yetişkinlerle ve ailelerle okuma organizasyonlar düzenlenebilir. Ödül ve hediye olarak kitap kullanılabilir."

Öğretmenler okuma alışkanlığı kazanmak için “öğrencilerden kendi kütüphanesindeki kitapları ödünç verme, günün planlanan bir saatinde aksatmadan okuma yapma, gece yatarken kitap okuma resimlerini paylaşma" gibi önerilerde bulunmaktadırlar. Öğretmenlerin okuma alışkanlığı kazandırma ile ilgili öğrencilere önerilerinden biri aşağıda aynen gösterilmiştir

Ö.23. "Farkl masal ve hikâyeler okuyarak okuma merakı geliștirme, okunan bir hikâyeyi canlandırma ve velileriyle beraber kitap okumalarını öneririm."

Öğretmenlerin okuma alışkanlığı kazandırmak için kullanılacak materyallerle ile ilgili önerileri ise, "kitapların sonunda hikâye ile ilgili etkinlikler, bilmeceler, resim boyama gibi etkinlikler olmalı, harf puntoları öğrencilerin yaşına uygun olmalı" gibi önerilerde bulunmaktadırlar. Öğretmenlerin okuma materyallerinde bulunması gereken özelliklerle ilgili öğrencilere önerilerinden biri aşağıda aynen gösterilmiştir.

Ö.43."...renkli, resimli, kaliteli kâğıtlara basılmış hikâyelerle başlamak. ... çocuğun ilgi alanı ile ilgili hikayelerin alınmast."

Araştırmaya katılan öğretmenlerin öğrencilere okuma alışkanlığı kazandırma konusunda Milli Eğitim Müdürlüğü, okul müdürlüğü ve velilerden beklentileri Tablo 4'te sunulmuştur.

Tablo 4. Okuma Alıșkanlığı Kazandırma Konusunda Öğretmenlerin Milli Eğitim Müdürlüğü, Okul Müdürlüğü ve Velilerden Beklentileri

\begin{tabular}{ll}
\hline \multicolumn{2}{c}{ Öğretmenlerin okuma alışkanlığı kazandırma konusundaki } \\
beklentileri
\end{tabular}




\begin{tabular}{ll}
\hline okuma saatleri düzenleme & *Farklı okuma ortamları oluşturma \\
*Kütüphaneleri bedava kek & *Velilerle birlikte okuma saatleri \\
ve çay ikram ederek cazip & düzenleme \\
hale getirme & *Ünlü kişilerin katılımıyla birlikte \\
*Kitap fuarları düzenleme & okuma \\
*Toplu taşıma araçlarına & *Okuduklarını paylaşmak için \\
okumayı özendirici afiş vb. & kütüphaneleri daha işlevsel hale \\
yerleştirme & getirme \\
*Toplu taşıma araçlarında & *Ücretsiz kitap dağıtma \\
kitaplıklar oluşturma & *Kitap okuma sınavı yapma \\
*Çocuklara kitap harçlığı & *Okuma salonlarını okulun en \\
verme & keyifli yeri haline getirilme \\
*Ders kitaplarını & *Okullara gazete, dergi alma. \\
öğrencileri cezbedici resim, & *Sürekli yayınlara (çocuk dergileri, \\
karikatür vb. & bilim-çocuk dergileri, çizgi \\
zenginleştirme & romanlar) abone olma. \\
*Kitap fuarlarına ulaşım & *Her hafta sonu çok kitap \\
imkânı sağlama & okuyanları ödüllendirme ve okul \\
*Kitap okuma sayılarına & panosunda teshir etme \\
göre ilde derece alanları & *Velilerle okuma şenlikleri \\
ödüllendirme & düzenleme \\
*Model olabilecek & \\
yazarları davet ederek & \\
öğrencilerle söyleşi & \\
yaptırma & \\
\hline &
\end{tabular}

Öğretmenlerin okuma alışkanlığı kazandırma konusunda okul müdürlüğünden beklentileri, Millî Eğitim Bakanlığı ve Milli Eğitim Müdürlüğü'nden beklentileri, okul müdürlüğünden beklentileri olmak üzere 2 temaya, bu temalar da kendi içinde alt temalara ayrılarak Tablo 4'te gösterilmiştir.

Tablo 4'e bakıldığında öğretmenlerin MEB ve Milli Eğitim müdürlüğünden en çok "okullara kitap takviyesi yapma ve çok kitap okuyan çocukları afiş ya da bilbordlarda gösterme”lerini bekledikleri görülmektedir. Öğretmenlerin bununla ilgili ifadelerinden biri aşağıda aynen gösterilmiştir.

Ö.2 “..... Başarll ögrencilerin çok kitap okuduklart tespitinin MEM ve bakanlıkça halka hissettirilmesine yönelik bilbord, afiş vb. uygulamaların yapılması uygun olur"

Öğretmenlerin okul müdürlüğünden en çok “okula küçük de olsa bir kütüphane açma, sınıflarda okuma köşesi için rahat minder ve oturaklar oluşturma, yazar ve kitap ile öğrencileri buluşturma" gibi beklentileri olduğu görülmektedir. Öğretmenlerin bununla ilgili görüşlerinden biri aşağıda aynen gösterilmiştir.

Ö.38. “Okul müdürlüğünün okuma odaları, koridorları, ilgi çekici kitap ve kitaplıklar, tanınmış kişilerin katılımı ile gerçekleşecek okuma etkinlikleri, sosyal medyada yayınlanacak ilginç okuma videoları, ...konulması için gerekli girişimlerde bulunmasını beklerim.",

Öğretmenlerin velilerden beklentilerinin başında çocuklarına örnek olma ve öğretmen, veli ve çocukla birlikte okuma saati düzenleme gelmektedir. Bu bakımdan okuma alışkanlığı kazandırmak için velilerin de sürece katkıda bulunması, üzerine düşen sorumluluğu yerine getirmesi olmazsa olmaz davranışlar arasında gösterilmektedir.

\section{Tartışma, Sonuç ve Öneriler}

Araştırma bulgularından yola çıkılarak aşağıdaki sonuçlara ulaşılabilir:

Öğrencilere okuma alışkanlığı kazandırmak yalnızca okulun ve öğretmenin görevi değildir. $\mathrm{Bu}$ süreçte $\mathrm{MEB}$, Milli Eğitim Müdürlüğü, okul müdürlüğü, öğretmen ve veli iş birliği içinde hareket etmelidirler.

Okuma alışkanlığı kazandırmak için öğretmenlerin takip ettikleri farklı stratejiler bulunmaktadır. $\mathrm{Bu}$ stratejilerle ilgili olarak öğretmenlerin deneyimlerini paylaştıkları sürece okuma sürecine önemli katkılar sağlayabilir. $\mathrm{Bu}$ stratejilerden bazıları öğrencide okuma isteği oluşturmaya yönelik (renkli, çekici kitaplar verme, en çok kitap okuyanı kitap kurdu seçme, tatilde okuyanlarla ilgili görseller sunma, okurken mutlu olan çocuk resimleri gösterme, okuma sırasında tütsü yakma, enstrüman dinleme, kitap ve yazar tanıtımı yapma gibi) stratejilerdir.

Alanda yapılan araştırmalara bakıldığında; ilkokul çağına gelinceye kadar çocuklar henüz okuma bilmediği için onlara albenisi olan çekici resimli kitaplar verilmelidir (Bus, \& Van IJzendoorn, 1995; Scarborough, \& Dobrich, 1994; Crain-Thoreson, \& Dale, 1992; Baker, Deborah, \& Kirsten, 1997; Dunning, Mason, \& Stewart, 1994; Lonigan, 1994). Başka bir araştırmaya göre, okuma alışkanlığının kazanılmasında bireyin bulunduğu toplumun değer sitemi ve ekonomik sistemi büyük bir öneme sahiptir. Okumayı aile de ödüllendirmektedir. Çocuğunu kütüphaneye götürerek, çocuğuna kitaplar hediye ederek önemli katkıda bulunmalıdır (Sağlamtunç, 1989). Dolayısıyla, alan yazınla bu araştırmanın sonuçları arasında benzerlikler olduğu söylenebilir. Stratejilerin diğer bir kısmı (evde okulda okuma saatleri düzenleme, kitapta anlatılanların resmini yaptırma, okunan kitaplar üzerinde konuşma, değişik mekânlarda okuma, görsellere bakarak hikâye yazma, hikâye haritası oluşturma vb.) da uygulamaların etkili ve verimli yapılması amacına yöneliktir. $\mathrm{Bu}$ sonuçlar alan yazındaki (Scarborough, \& Dobrich, 1994; Crain-Thoreson, \& Dale, 1992; Baker, \& diğerleri 1997; Bus, \& Van IJzendoorn, 1995; Dunning, Mason, \& Stewart, 1994; Lonigan, 1994; Jacobs, Marrison, \& Swinyard, 2000; Sağlamtunç, 1989; Tanju, 2010) araştırma bulguları ve görüşlerle benzerlik göstermektedir. Ayrıca Güngördü'nün (2006) “Çocukların okuma alışkanlığı kazanamamasında en önemli etkenlerden birisi nitelikli kitaplarla tanıştırılmamış olmalarıdır. Bu konuda yazar ve şairlere, gazete, radyo ve televizyon kuruluşlarına ve kitabevlerine önemli görevler düşmektedir." görüşü bu araştırmanın sonucunu destekler niteliktedir.

Öğretmenlerin okuma alışkanlığı kazandırma konusunda karşılaştıkları sorunların aileden, öğretmenden, çevreden ve öğrenciden kaynaklandığı belirlenmiştir. Aileden kaynaklanan sorunlar, okuma alışkanlığı kazandırma konusunda çocuğa iyi bir model olmama, kayıtsız kalma, sevmedikleri halde ağabey ve ablalarının okudukları kitapları çocuklara zorla okutmaya çalışma gibi davranışlardan kaynaklanmaktadır. Bu sonuçlar, alan yazındaki (Gürler, 1999; Jensen, Papp, \& Richmond, 1998; Sünbül ve diğerleri, 2010; Yılmaz, 1993) araştırma bulguları ve görüşlerle benzerlik göstermektedir. Okuldan (öğretmenden) kaynaklanan sorunlar, çocuğun yaşına, ilgi alanına uygun olmayan kitapları okumaya zorlanması 
olarak tespit edilmiştir. Bu sonuçlar, Karaşahin (2009), İpşiroğlu (1997), Jones (1996); Ülper, (2011) ve Wilhelm'in (1997) araştırma bulguları ve görüşlerini destekler niteliktedir. Öğrenciden kaynaklanan sorunlar ise okumaya ilgi ve isteklerinin olmaması, okuma hılarının yavaş olması olarak tespit edilmiştir. Bu sonuçlar, Aksoy ve Öztürk (2018) ve EARGED'in (2007) araştırma bulgularıyla benzerlik göstermektedir. Çevreden kaynaklanan sorunlar daha çok öğrencilerin internet, tv ve telefonlara fazla vakit ayırmalarından kaynaklanmaktadır. TÜİK'in (Akt. Bugün, 2014), Sever ve diğerleri'nin (2013), Yalınkılıç ve Ülper 'in (2001), Özgen'in (1999) araştırma sonuçları bu araştırmayı destekler niteliktedir.

Öğretmenlerin okuma alışkanlığı kazandırma konusundaki önerileri aileye, okula (öğretmene), öğrenciye ve okuma materyallerine yönelik öneriler olarak tasnif edilmiştir. Aileye yönelik öneriler daha çok okuyarak örnek olma, çocukla birlikte evde ve okulda okuma faaliyetlerine katılma, çocuğa hediye kitap alma, evde küçük çapta da olsa bir kitaplık oluşturma ve tv, telefon, bilgisayar gibi araçların kullanım süresini kısıtlama olarak tespit edilmiştir. $\mathrm{Bu}$ sonuçlar, Goodman ve Goodman'ın (1982) ve Gambrel'in (1981) araştırma bulgu ve görüşleriyle benzerlik göstermektedir. Okula öğretmene yönelik öneriler veliyi sürece katmak için teşvik etme, filmi yapılmış kitapları okutma, öğrencileri imkânlar ölçüsünde velilerin de katılımı ile kütüphaneye götürme, kendisi de okuyarak örnek olmaya çalışma, hikâye haritası yaptırma, masal sonu tamamlatma, kuklalar kullanma, öğrencilere belirledikleri konularda hikâye yazdırma, okunan kitaplar üzerinde konuşma gibi faaliyetlerden oluşmaktadır. Bu sonuçlar, okuma alışkanlığı kazandırmada sorumluluğun öğretmenlerde olduğunu savunan (Arıcı, 2005; Wilhelm, 1997; Tanju, 2010; Lickteig, \& Russell, 1993; ve Suna (2006) araştırma bulgu ve görüşleri ile farklılık göstermektedir. Çünkü, bu araştırmada sorumluğun velilerle paylaşılması gerektiği sonucuna ulaşılmıştır.

Öğrenciye yönelik öneriler, kütüphanesindeki kitapları ödünç verme, gece yatarken kitap okuma resimlerini paylaşma, sevecekleri kahramanların bulunduğu, ilgilerini çeken kitaplar seçme, okuduklarını öğretmenle paylaşma gibi uygulamalardan oluşmaktadır. Bu sonuçlar, Çakmak ve Yılmaz (2009), Jones (1996) ve Jacobs, Marrison ve Swinyard'ın (2000) görüşleriyle benzerlik göstermektedir. Okuma materyallerine yönelik öneriler ise kitapların sonunda hikâye ile ilgili etkinlikler, bilmeceler, resim boyama vs. etkinlikler olması, harf puntolarının öğrencilerin yaşına uygun olması, resim, yazı ve sağlamlık yönünden iyi olması ve albenisinin iyi olması gibi özelliklerden oluşmaktadır.

Öğretmenlerin okuma alışkanlığı kazandırma konusundaki beklentileri, “MEB ve Milli Eğitim Müdürlüğü’nden beklentiler, okul müdürlüğünden beklentiler ve velilerden beklentiler olarak tasnif edilerek analiz edilmiştir. Öğretmenlerim MEB ve Milli Eğitim Müdürlüğü'nden beklentileri okullara kitap takviyesi yapma, her sınıfa kitap seti gönderme, çok kitap okuyan çocukları afiş ya da bilbordlarda gösterme, Türkçe dersi haricinde okuma saati koyma, aylık güncel, bilimsel dergiler gönderme, iyi okuyan öğrencileri aileleri ile birlikte haftalık kamplara gönderme, okumayı geliştirici projeler düzenleme, sosyal medyada yayınlanacak ilginç okuma videoları hazırlama, okullara kütüphane kurmayı destekleme, kamu spotları yaparak aileleri bilinçlendirme ve seviyelerine uygun metinleri Türkçe kitaplarına yerleştirme olarak tespit edilmiştir.

Öğretmenlerin okuma alışkanlığı kazandırma konusunda okul müdürlüğünden beklentileri, küçük de olsa okula bir kütüphane kurma, sınıf ve okul kitaplıklarını her yıl yenileme, yazar kitap ve öğrencileri buluşturma, sınıflarda okuma köşesi için rahat minder ve oturaklar oluşturma, kütüphanelere öğrencilerin seviyelerine uygun TÜBİTAK kitapları alma, kitap fuarı, kütüphane gibi yerlere gezi düzenleme, hikaye yazan öğrencileri ödüllendirme, ünlü kişilerin katılımıyla birlikte okuma etkinlikleri yapma gelmektedir. Bu sonuçlar, Çetin ve Karaata (2010), Curtis ve Longo (1999), Bus ve van Ijendoorn (1995), Morrow, Gambrell ve Pressley (2003), Strommen, ve Mates (2004) ve Wilhelm'in (1997) araştırma bulguları ve görüşleriyle benzerlik göstermektedir. Görüldüğü gibi literatürle öğretmenlerin beklentileri birçok yönden örtüşmektedir.

Öğretmenlerin velilerden beklentileri ise kendisi okuyarak çocuklarına örnek olma, öğretmen, veli ve çocukla birlikte okuma saati düzenleme, kitapçılara ve kitap fuarlarına götürme, evlerde uygun okuma ve okunanları değerlendirme ortamları oluşturma, sınıf kitaplığı oluşturmaya destek verme, kitap için bütçe ayırarak çocuğun istediği kitapları alma ve bebeklik döneminden itibaren kitapla tanıştırmadır. Alan yazına bakıldığında velilerin kendilerinin okuyarak çocuklarına model olmaları gerektiği (Tanju, 2010; Suna, 2006; Jacobs, Marrison, \& Swinyard, 2000) okul ve sınıf kitaplıklarının işlevsel hale getirilmesi (Çakmak ve Yılmaz, 2009; Jones, 1996), bebeklik yaşlarında kitapların resimlerine ve okunan kitaplardaki kelimelerin seslendirilmesi, evde bir kitaplık oluşturulması, çocuklara oyuncaklarla birlikte kitap alınması (Bus, \& van IJendoorn, 1995), evde okuma zamanları oluşturma, okunan kitaplar üzerinde konuşma, kitabevleri ve kitap fuarlarına gezi düzenleme (Lickteig, \& Russell, 1993; Sofuoğlu, 1979) yönündeki görüş ve öneriler bu araştırmanın sonuçlarını önemli oranda destekler niteliktedir.

Bu sonuçlardan hareketle şu önerilerde bulunulabilir:

1. Öğretmenlere, öğrencilere okuma alışkanlığ kazandırmak için takip edecekleri stratejileri içeren seminer ve kurslar düzenlenebilir.

2. Okuma alışkanlığı kazandırma konusunda deneyimlerin paylaşılabileceği (EBA vb.) değişik platformlar oluşturularak, başarılı uygulamalar tanitılabilir.

3. İyi okuyan öğrencileri onurlandırmak ve motive etmek amacıyla okul çapında, il çapımda hatta ülke genelinde programlar düzenlenebilir.

4. Velileri sürece katmak amacıyla ülke genelindeki ilkokulları kapsayan MEB'in koordine ettiği projeler düzenlenebilir.

\section{Kaynakça}

Aksoy, E. ve Öztürk, D. S. (2018). Öğrencilerdeki okuma alışkanlığının öğretmen ve öğrenci görüşlerine göre belirlenmesi. Türkiye Sosyal Araştırmalar Dergisi, 22 (1), 143-184. 
Akbayır, S. (2009). Çocuğum neyi okumalı? Ankara: Pegem Yayınları.

Arıc1, A. F. (2005). Ilköğretim ikinci kademe öğrencilerinin okuma durumlarl (beceri-ilgi alışkanlık-eğilim). (Doktora tezi). Yükseköğretim Kurulu Ulusal Tez Merkezi'nden edinilmiştir. (Tez No.162923).

Baker, L., Deborah, S., \& Kirsten, M. (1997). Home and family influences on motivations for reading. Educational Psychologist, 32, 69-82.

Balc1, A. (2003). Bir okuma materyali olarak çocuk dergileri ve "çocuklara rehber". TUBAR, 13, 319-349.

Bayram, O. (1990). Illkokul çă̆ çocuklarının okuma alışkanlığl ve Yenimahalle İlçe Halk Kütüphanesi Gezici Kütüphane Hizmeti. (Yüksek lisans tezi). Yükseköğretim Kurulu Ulusal Tez Merkezi'nden edinilmiştir. (Tez No. 12432).

Bugün (2014). TÜİK’ten utandıran kitap okuma raporu. https://1000 kitap.com/haber. Erişim Tarihi. 15.02.2019.

Bus-Adriana, G., \& Yan, I., Marinus, H. (1995). Mothers reading to their 3 year olds: The role of mother-child attachment security in becoming literate. Reading Research Quarterly, 30, 998-1015.

Büyüköztürk, Ş., Çakmak-Kılıç, E., Akgün, Ö. E., Karadeniz, Ş. ve Demirel, F. (2012). Bilimsel araştırma yöntemleri (13. bask1). Ankara: Pegem Akademi.

Calp, M. (2010). Özel eğitim alanı olarak Türkçe öğretimi. Ankara: Nobel Yayıncılık.

Cohen, L., Manion, L., \& Morrison, K. (2007). Research methods in education (6th ed.). New York: NY, US. Francis Group.

Creswell, J. W. (2013). Nitel araştırma yöntemleri: Beş yaklaşıma göre nitel araştırma ve araştırma deseni. Ankara: Siyasal Kitabevi.

Curtis, M. E., \& Longo, A. M. (1999). When adolescents can't read: Methods and materials that work. Brookline Books. Cambridge: MA.

Çakmak, T. ve Yılmaz, B. (2009). Okul öncesi dönem çocuklarının okuma alışkanlığına hazırlık durumları üzerine bir araştırma: Hacettepe Üniversitesi Beytepe Anaokulu örneği. Türk Kütüphaneciliği, 23(3), 489-509.

Çetin, Y. ve Karaata, C. (2010). Türk öğrencilerin kitap okumama sorununa çözüm önerileri. Ç. Ü. Sosyal Bilimler Enstitüsü Dergisi, 19(1), 202-215.

Crain, T., Catherine, \& Dale, P. S. (1992). Do early talkers become early readers? Linguistic precocity, preschool language, and emergent literacy. Developmental Psychology, 28, 421-429.

Devrimci, H. (1993). Illkokul 5. sınıf çocuklarında okuma alışkanlığının incelenmesi. (Bilim uzmanlığg tezi). Yükseköğretim Kurulu Ulusal Tez Merkezi'nden edinilmiştir. (Tez No. 31510).

Dökmen, Ü. (1994). Okuma becerisi, ilgisi ve alışkanlı̆̆ üzerine psikososyal bir araştırma. İstanbul: MEB Yayınları.
Dunning, D. B., Mason, J, M., \& Stewart, Janice, P. (1994). Reading to preschoolers: A responseto scarborough and dobrich and recommendations for future research. Developmental Review, 14, 324-339.

EARGED. (2007). Öğrencilerin okuma düzeyleri, Ankara: https://www.meb.gov.tr/earged/earged/okuma_duzey.pf. Erişim Tarihi.21.01.2020.

Goodman, K., \& Goodman, Y. (1982). Spelling ability of a self-taught reader. F. Gollasch (Ed.), Language and Literacy: The selected works of Kenneth S. Goodman, 2, içinde, ss. 22-1226. London: Routledge ve Kegan Paul.

Gönen, M., Öncü, E. Ç. ve Işıtan, S. (2004). Illköğretim 5., 6. ve 7. sınıf ögrrencilerinin okuma alışkanlıklarının incelenmesi. Milli Eğitim Dergisi, https://dhgm.meb. gov.tr/yayimlar/dergiler. Erişim Tarihi: 28 Mart 2019.

Gudakovska, I. (1996). Students' reading habits in latvia. Journal of Adolescent \& Adult Literacy, 40(1), 64-68.

Güngördü, E. (2006). Okuma alışkanlığı edinme sürecinde sınıf öğretmeninin sorumluluğu. Gazi Üniversitesi ulusal sınıf ögretmenliği kongresi bildiri kitabl. 1. Ankara: Pegem Akademi.

Gürcan, H. İ. (1996). Okuma alışkanlığl ile kitap yayımcılı̆̆ının kültürel iletişim ve teknolojisine bă̆lı sorunları karşısında Türkiye koşulları temelinde bir model önerisi. (Doktora tezi). Yükseköğretim Kurulu Ulusal Tez Merkezi'nden edinilmiştir. (Tez No.51386)

Gürler, Ü. (1999). Çocuk kitapları ve anne-babaların bu konudaki tutumları üzerine bir inceleme. (Yüksek lisans tezi). Yükseköğretim Kurulu Ulusal Tez Merkezi'nden edinilmiştir. (Tez No. 81914).

İpşiroğlu, Z. (1997). Eğitimde yeni arayışlar. İstanbul: Adam Yayınları.

Jacobs, J. S., M., Timothy G., \& Swinyard, W. R. (2000). Reading aloud to students: Anational probability study of classroom reading practices of elementary school teachers. Educational Pychology, 21, 171-193.

Jensen, K., Papp, S., \& Richmond, B. (1998). Improving çhildren's habits in recreational reading. Chicago: Saint Xavier University \& IRI/Skylight Field-Based Masters Program.

Jones, W. F. (1996). Teachers as readers/students as readers. Sustaining the vision. (pp: 17-21) Conference of the International Association of School Librarianship, England.

Karaşahin, M. (2009). İlköğretim ve ortaöğretim okullarında görev yapan ögretmenlerin okuma kültürlerinin değerlendirilmesi. Ankara: MEB, Eğitimi Araştırma ve Geliştirme Daire Başkanlığı.

Lickteig, M. J., \& Russel, J. F. (1993). Elementary teachers' read-aloud practice. Reading Teacher, 30, 202-208.

Lonigan, C. J. (1994). Reading to preschoolers exposed: is the emperor really naked? Developmental Review, 14, 303-323.

Maraşl1, A. (2005). Okumayı sevdirme yolları. İstanbul: Bilge Yayıncilık. 
MEB (2018). Türkçe öğretim programı: Ankara: Millî Eğitim Bakanlığ 1 .

Miles, M. B., \& Huberman, A. M. (1994). Qualitative data analysis: An expanded sourcebook. (2nd ed). Thousand Oaks: CA Sage.

Morrow, L. M., Gambrell, L. B., \& Pressley, M. (2003). Best practices in literacy instruction (2nd ed.). New York: Guilford.

Olcay, B. (1990). İlkokul çă̆l çocuklarının okuma alışkanlığl ve Yenimahalle İlçe Halk Kütüphanesi Gezici Kütüphane Hizmeti. (Yüksek Lisans Tezi). Yükseköğretim Kurulu Ulusal Tez Merkezi'nden edinilmiştir. (Tez No.12432).

Özen, F. (2001). Türkiye'de okuma alışkanlığı. Ankara: Kültür Bakanlığı Yayınları.

Özgen, B. (1992). Okuma alışkanlığı üzerine. ABC Dergisi, $72,6-8$.

Patton, M. Q. (2005). Qualitative research. New York: John Wiley \& Sons, Ltd.

Sağlamtunç, T. (1989). Türk gençlerinin okuma alışkanlıkları, Türkiye'de ve Almanya Federal Cumhuriyeti'nde gençlere yönelik kütüphane hizmetleri, Ankara: http://genclikbirikimi.org/kunye. Erişim Tarihi: 21.01.2020.

Sağlamtunç, T. (1990). Türkiye'de üniversite kütüphanecilik bölümlerinin 4. sınıf öğrencilerinin özgür (boş) zaman-ders dışı okuma alışkanlıkları üzerine bir araştırma. Türk Kütüphaneciliği, 4(1), 3-21.

Scarborough, H. S., \& Dobrich, W. (1994). On the efficacy of reading to preschoolers. Developmental Review, 14, 245-302.

Sever, S., İnce-Samur, A. Ö., Doğan, B. N., Çıldır, B. ve Bulut, S. (2013). Illkokul 4. sinıf ögrencilerinin okuma kültürü edinme düzeyleri ile kitle iletişim araçlarını kullanma alışkanlıklarının incelenmesi. İstanbul: I. Türkiye Çocuk ve Medya Kongresi Bildiriler Kitabı, Çocuk Vakfi Yayınları.

Sofuoğlu-Gönen, M. (1979). Anaokullarına giden 5 ve 6 yaş çocuklarının seçilmiş resimli kitapları hakkında beğenilerinin incelenmesi, Ankara: T.K.D.B. 28(3), 151-156.

Sünbül, A. M., Yılmaz, E., Demirer, V., Ceran, D. Işık, A., Çintaş, D., Çalışkan, M. ve Alan, S. (2010). Illkögretim ögrencileri kitap okuma alışkanlıkları: Konya ili araştırma raporu. (5-6-7-8. Sinıflar). Konya: Selçuk Üniversitesi

Staiğer, R. C. (1979). Roads to reading. Paris: UNESCO.

Strommen, L. T., \& Mates, B. F. (2004). Learning to love reading: Interviews with older children and teens. Journal of Adolescent ve Adult Literacy, 48, 188-199.

Suna, Ç. (2006). Illköğretim öğrencilerinin okuma ilgi ve alışkanlıklarını etkileyen etmenlerin analitik olarak incelenmesi ve değerlendirilmesi, (Yüksek lisans tezi). Yükseköğretim Kurulu Ulusal Tez Merkezi'nden edinilmiştir. (Tez No.187992).

Tanju, E. H. (2010). Çocuklarda kitap okuma alışkanlığı'na genel bir bakış. Sosyal Politika Çalışmaları Dergisi, 21, 30-39.

Türk Dil Kurumu (TDK) (2019). Türk Dil Kurumu Sözlükleri, https://sozluk.gov.tr/?kelime, Erişim Tarihi: 29 Aralık 2019.

Ülper, H. (2011). Öğrenci açısından okumaya güdüleyici etmenler. Kuram ve Uygulamada Eğitim Bilimleri, 11(2), 941-960.

Vogt, W. P., Gardner, D. C., \& Haeffele, L. M. (2012). When to use what research design. New York: Guilford Press.

Wilhelm, J. D. (1997). You gotta be the book: teaching engaged and reflective reading with adolescents. New York: Teachers College Press.

Yavuzer, H. (2012). Çocuk psikolojisi. İstanbul: Remzi Kitabevi.

Yıldırım, A. ve Şimşek, H. (2011). Sosyal bilimlerde nitel araştırma yöntemleri (8th ed.). Ankara: Seçkin Yayınevi.

Yılmaz, B. (2012). Okumanın nörobiyolojisi. Türk Kütüphaneciliği, $\quad$ 26(1), 142-14. 